\title{
Tritiated Liquid Waste Packaging
}

\author{
Emil A. Mershad, William W. Thomasson
} and Joyce J. Dauby

August 31, 1977

6? 10100

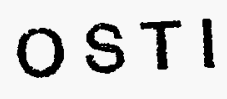

MOUND LABORATORV

Miamistourg。 (Ohỉ@

operated by

Monsanto

MONSANTO RESEARCH CORPORATION

a subsidilary of Monsanto Company

for the

UNITED STATES ENERGV RESEARCH

AND DEVELOPNIENT ADMINISTRATION

MAS

Goveminent Contract $N$ o. EY $=76=0=04=0053$

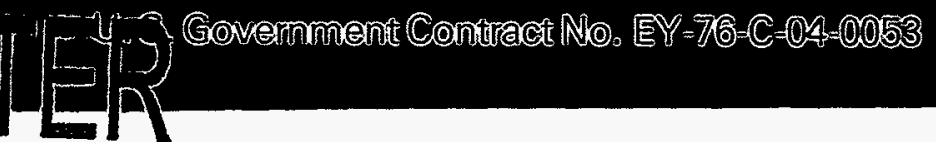

DISTRIBUTION OF THIS DOCUMENT IS UNLIMTED 


\section{NOTICE}

This report was prepared as an account of work sponsored by the United States Government. Neither the United States nor the United States Energy Research and Development Administration, nor any of thair employees, nor any of thoir contractors, subcontractors, or their employees, makes any warranty, express or impled, or assumes any legal llability or responsibility for the accuracy, completeness or usefulness of any information, apparatus, product or process dieclosed or represents that its use would not infringe privately onined rights. 


\title{
Tritiated Liquid Waste Packaging
}

\author{
Emil A. Mershad, William W. Thomasson and Joyce J. Dauby
}

Issued: August 31, 1977

PRINTED IN THE UNITEO STATES OF AMERICA

Available from

National Technical Information Service

U.S. Dipartment of Commerce

5285 Port Royal Rond

Springfleld, Viroinis 22161

Price: Printed Copy \$3.50; Microfiche $\$ 3.00$

\section{MONSANTO RESEARCH CORPORATION}

A Subsidiary of Monsanto Company

\section{MOUAD IABORATORY}

Miamisburg, Ohio

45342

operated for

\section{UNITED STATES ENERGY RESEARCH AND DEVELOPMENT ADMINISTRATION}

U. S. Government Contract No. EY-76-C-04-0053

\section{DISCLAIMER}

This report was prepared as an account of work sponsored by an agency of the United States Government. Neither the United States Government nor any agency thereof, nor any of their employees, makes any warranty, express or implied, or assumes any legal liability or responsibility for the accuracy, completeness, or usefulness of any information, apparatus, product, or process disclosed, or represents that its use would not infringe privately owned rights. Reference herein to any specific commercial product, process, or service by trade name, trademark, manufacturer, or otherwise does not necessarily constitute or imply its endorsement, recommendation, or favoring by the United States Government or any agency thereof. The views and opinions of authors expressed herein do not necessarily state or reflect those of the United States Government or any agency thereof. 


\section{Abstract}

An improved method for packaging tritiated waste liquids for burial is described and evaluated. The packaging procedure virtually eliminates tritium exposures to personnel and the environment. The package is shown to be more than adequate for burial of tritiated liquid wastes. Calculations based on tests of the package indicate that the maximum tritium released during $85 \mathrm{yr}$ (seven half-lives of tritium) burial would be 0.0028 of the total tritium contained in the package or approximately $1.6 \mathrm{Ci}$ from the $70,000 \mathrm{Ci}$ (recommended maximum) package.

\section{Introduction}

Operations conducted at Mound Laboratory include the routine handling of gram quantities of tritium in various research, development, and analytical systems. These operations produce radioactively contaminated effluents that must be processed to remove tritium, tritium oxide, and tritiated pump oil vapors prior to release of the effluent gases to the environment.

In the process of decontaminating the effluent gas stream, tritium-contaminated liquid wastes are collected. Because of increased emphasis on minimizing tritium release to the environment, considerable effort has been expended in areas of containment, safe handling, and disposal of tritiated liquid waste. Mound Laboratory has developed facilities and methods for the safe handling and packaging of this Iiquid waste.

Tritiated liquids are generated by vacuum and transfer pumps, processing and decontamination functions, drybox purification processes and the Effluent Removal System (ERS). Most of the tritiated water is collected by the ERS, but smail quantities are generated in drybox systems and collected in stainless steel condensate tanks. Waste oil from vacuum and transfer pumps is collected in steel tanks connected directly to pump drain lines.

The primary objectives of all tritiated waste packaging procedures are to:

- Minimize effluent releases and personnel exposure during packaging.

- Ensure integrity of the primary containment.

- Minimize tritium permeation to the secondary and tertiary containment.

- Prevent or minimize isotopic exchange with ground waters.

- Comply with ERDA shipping regulations for radioactive wastes.

- Meet DOT shipping requirements.

The Liquid Waste Packaging Facility (IWPF) at Mound Laboratory provides measurement, assay, and packaging for burial of tritium-contaminated water and liquid organics such as pump oils under total-containment conditions. Built in 1973, the facility was designed to effectively reduce the hazard of handiing liquid radioactive waste, -- both to 


\section{DISCLAIMER}

Portions of this document may be illegible in electronic image products. Images are produced from the best available original document. 
the operating personnel during processing and to the environment after burial. The procedure guidelines and the burial package reflect these objectives as of May 1976.

\section{Primary and Secondary}

\section{Packaging}

Waste liquids collected in the ERS storage tanks, water condensate tanks, pump oil reservoirs, or similar containers are analyzed and packaged in the Liquid Waste Packaging Facility (LWPF), which is shown in Figure 1. Special provisions must be made for waste liquids collected in nonstandard (for example, oversize) containers.

\section{Standard Containers .}

Pump oil reservoirs and water condensate tanks (see Figure 2) are removed from operating systems and transported to the LWPF where they are emptied inside inert enclosures into two calibrated volume holding tanks (see Figure 3). All waste liquids from the ERS are pumped via doublecontainment transfer lines into the LWPF holding tanks.

Wastewater is kept separated from pump oil waste; each is pumped into one of the two holding tanks. When a tank has been filled to approximately 100 liters of liquid, it is sampled. Mixing, prior to sampling, is accomplished by agitating the liquid with a stream of compressed aix from the bottom of the tank through a three-way valve. The air is vented to the ERS through a line at the top of the tank. An accurately measured one-liter sample is drawn from each tank into a bottle which is placed in an in-line calorimeter for analysis (see Figures 4 , 5 and 6 ). The accuracy of the analysis is $\pm 1 \mathrm{~mW}$ or $0.003 \mathrm{~g}$.

The primary/secondary burial package (see Table I for specifications) is prepared by inserting a 27-gal polyethylene drum* into an asphalt-coated 30 gal steel drum** (see Figure 7). The polyethylene drum is filled with either $81 \mathrm{~kg}(90$ liters) of a 3:1 dry mixture of plaster and cement for water or $9.5 \mathrm{~kg}(90 \mathrm{li}-$ ters) of vermiculite for organic (pump oil) wastes (see Figure 8). Absorbal [32 kg (90 liters)] may be substituted for packaging organic wastes. The steel drum is then sealed to the bottom of the LWPF inert enclosure for total containment during transfer of the Iiquid (see Figure 9).

After calorimetry the liquid waste is transferred, via a calibrated metering pump, into the polyethylene drum; the volume transferred is verified using calibrated sight glasses on the holding tanks (see Figure 3). A maximum of 35 liters of water or 28 liters of pump oil (experiments have shown these are the maximum fully absorbable amounts for a 27-gal polyethylene drum) are transferred into the polyethylene drum (see

*DOT specification 2S, polyethylene, 0.0625 in. minimum wall thickness, 27 gal capacity, closures to be two 2-in Buttress threaded fittings.

**DOT specification $17 \mathrm{H}, 18$ gauge body and head, 18.25 in. i.d., 12 gauge bolted ring, drop forged lugs, all external and internal surfaces coated with 10-15 mils of Cabot's FLEXIBLAC No. 3230 . 


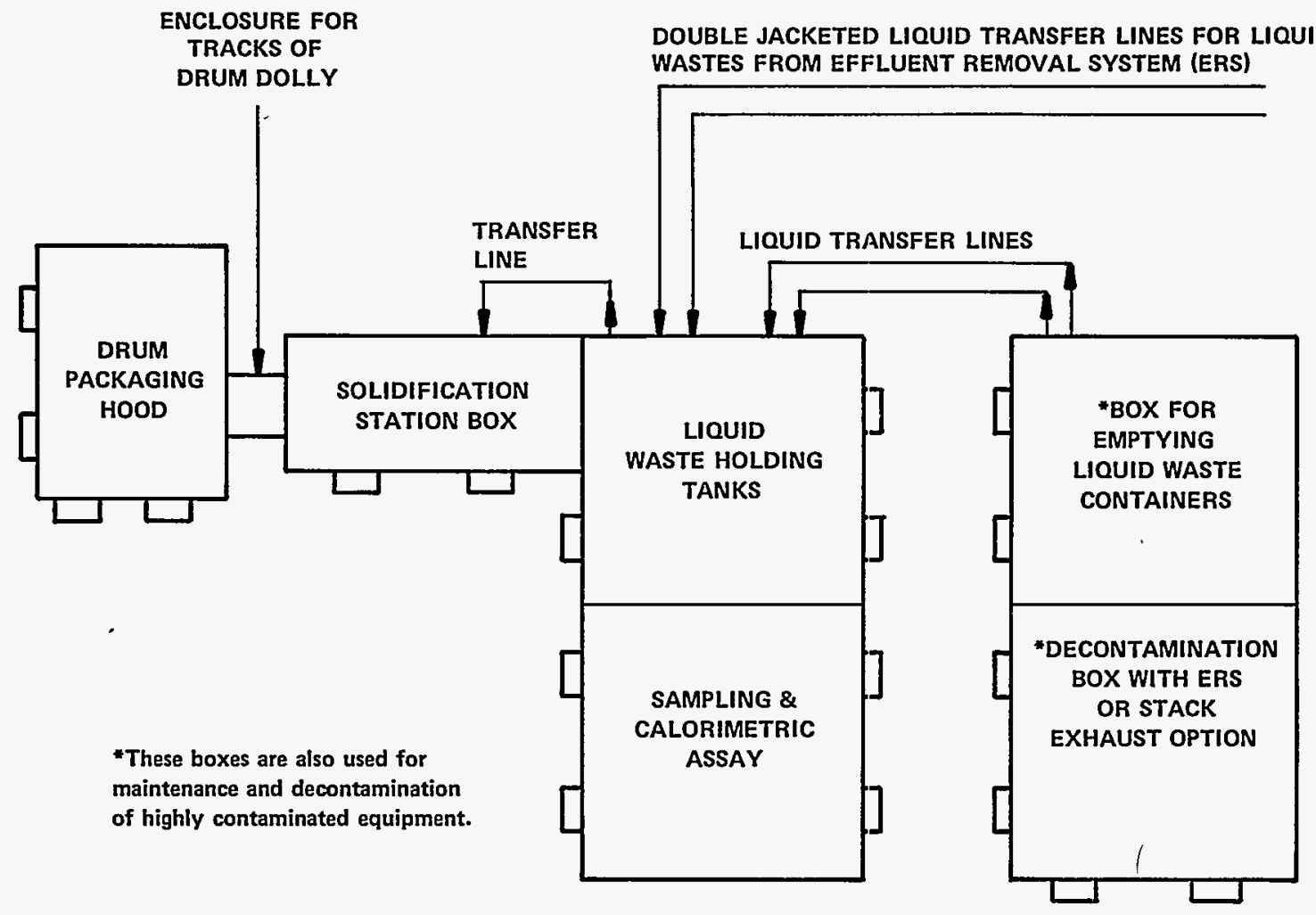

FIGURE 1 - Tritium liquid waste handling facility.

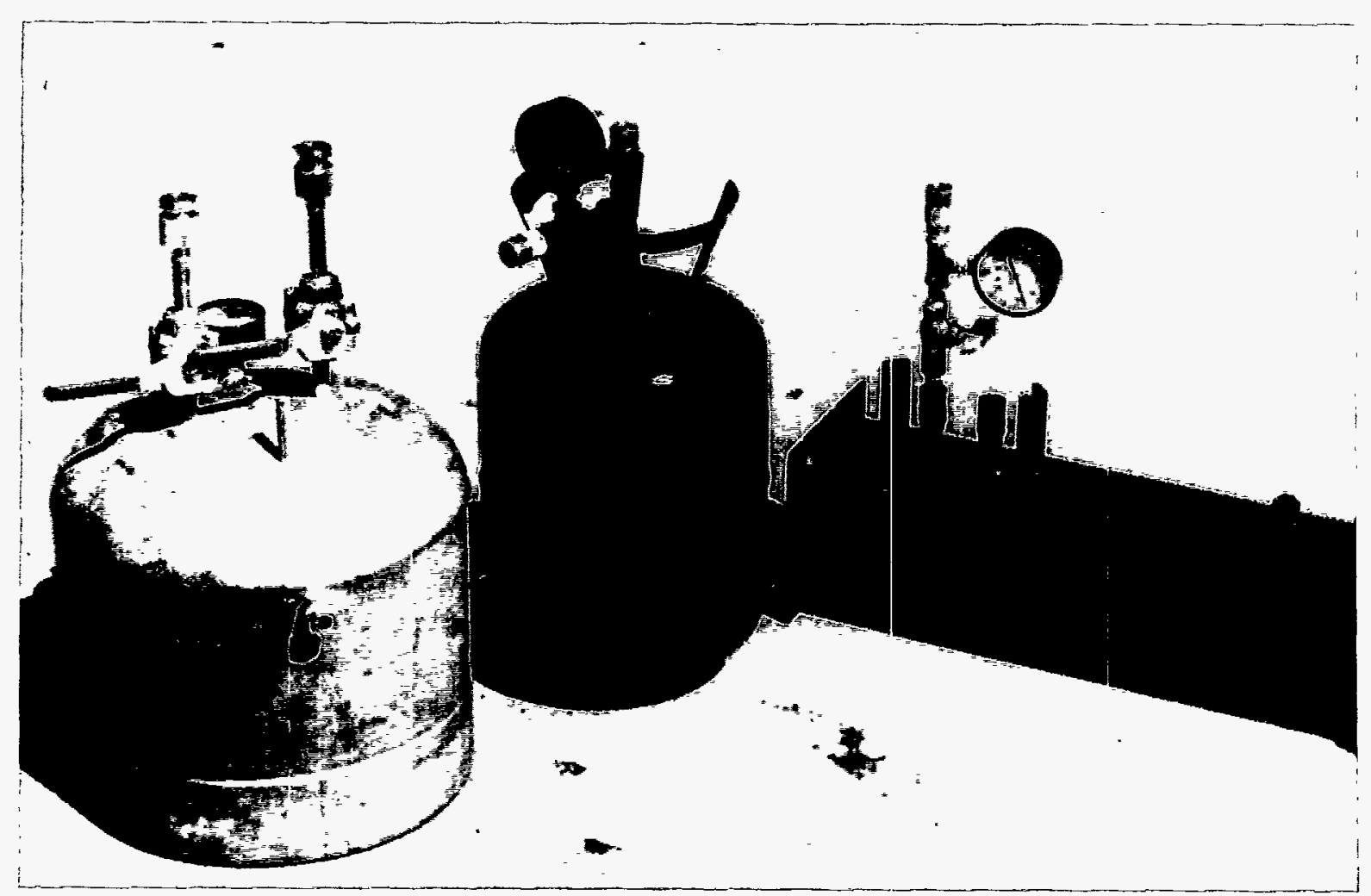

FIGURE 2 - Standard portable liquid waste containers. 


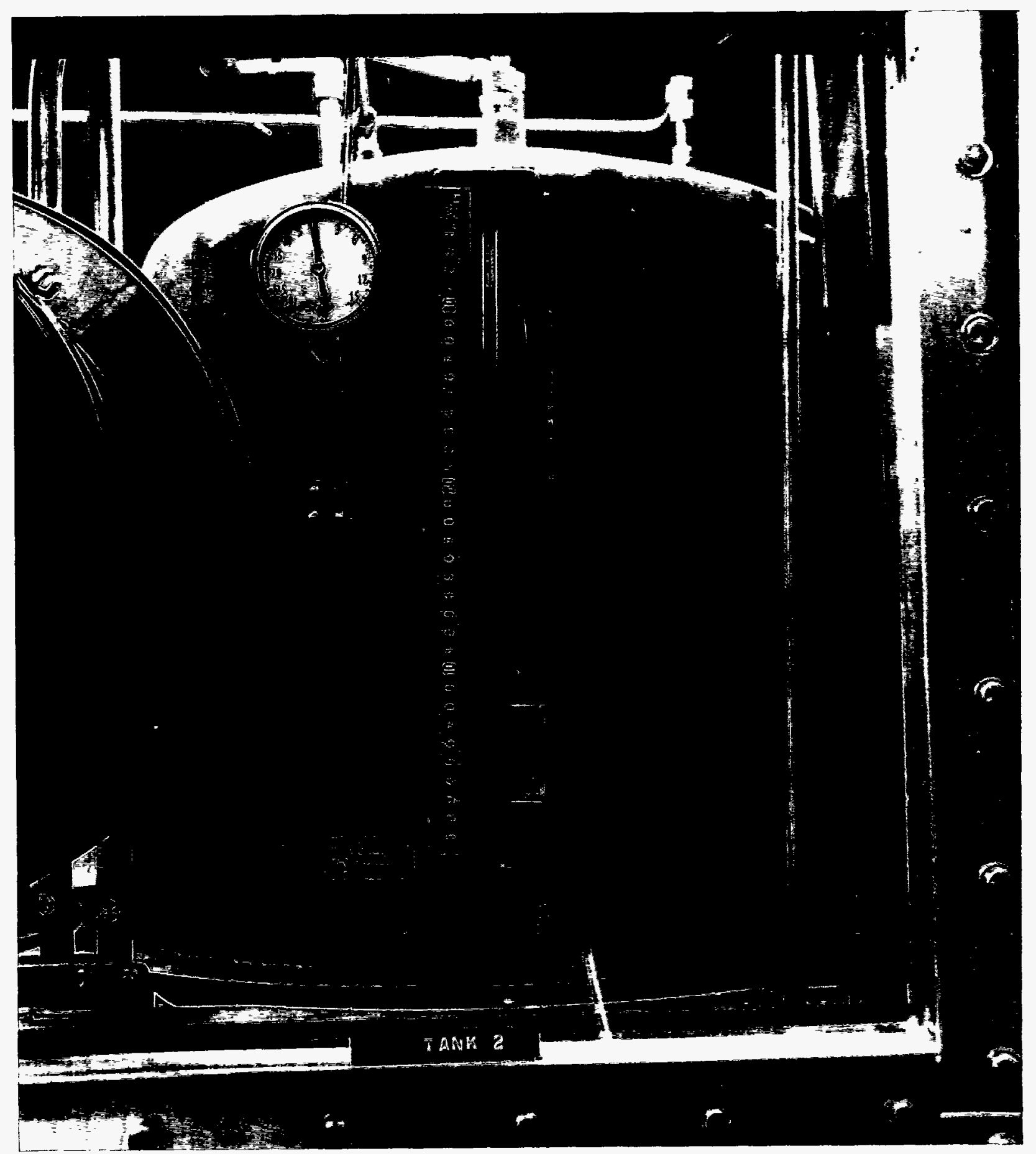

FIGURE 3 - One of two calibrated volume holding tanks (shown inside inert enclosure). 


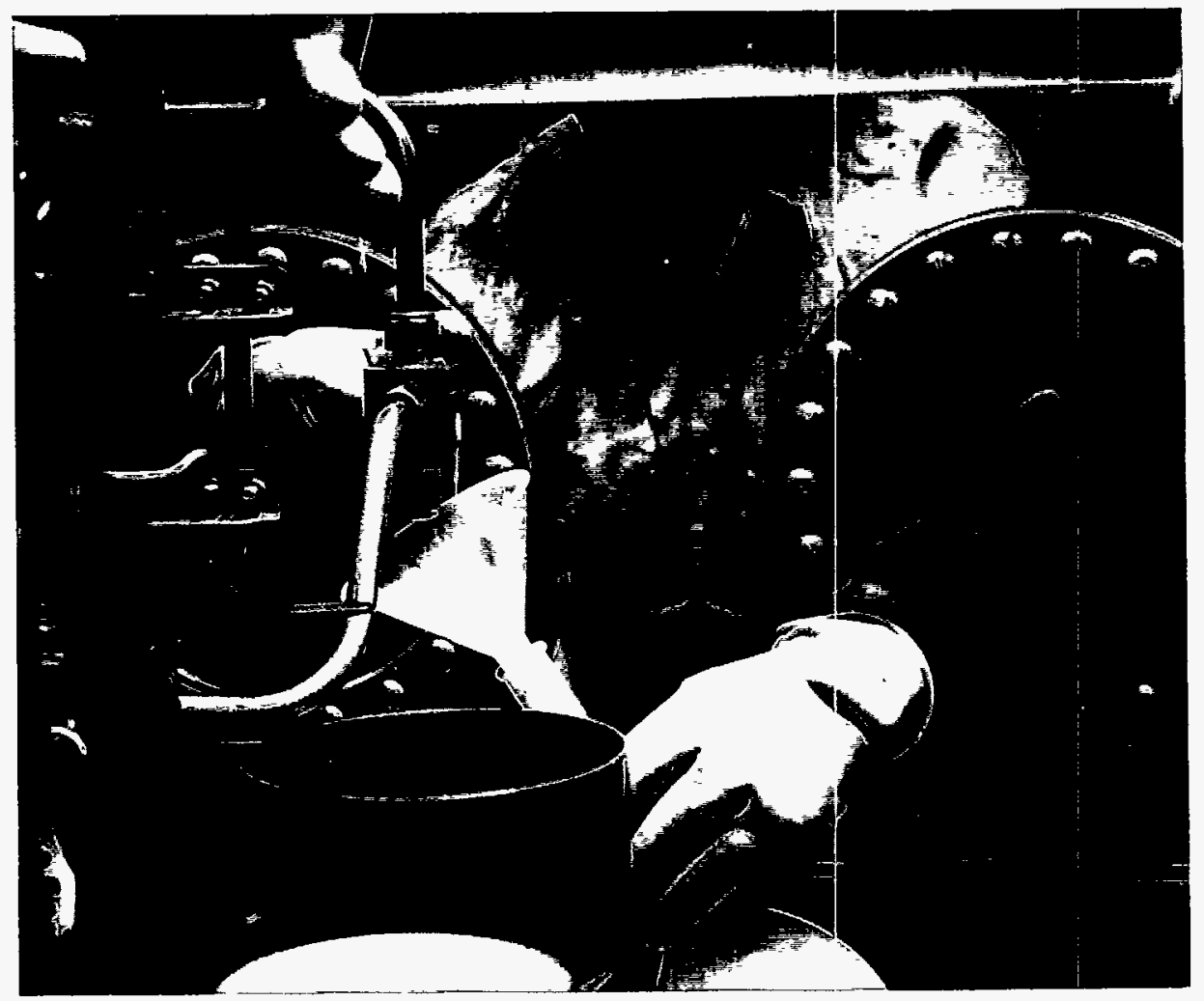

FIGURE 4 - One-liter sample being drawn from holding tank.

Table I - REQUIREMENTS FOR PRIMARY AND SECONDARY CONTAINERS-

1. The container must be constructed of rigid polyethylene, polypropylene, or equivalent corrosion and impact resistant material.

2. The container must have a leak-tight plastic lid.

3. The maximum size must not exceed the internal dimensions of a $30-$ gal $17 \mathrm{H}$ steel drum (secondary package).

4. The volume of liquid must be restricted to maintain a maximum ratio of one part water to three parts cement/ plastic mix or one part pump oil or water to four parts vermiculite or Absorbal. Experiments have shown these are the maximum amounts that can be completely absorbed.

5. The tritium content must not exceed $70,000 \mathrm{Ci}(7 \mathrm{~g})$ per 30-gal drum. The 7-g limit prevents excessive pressure in the package after complete decay of the tritium. 


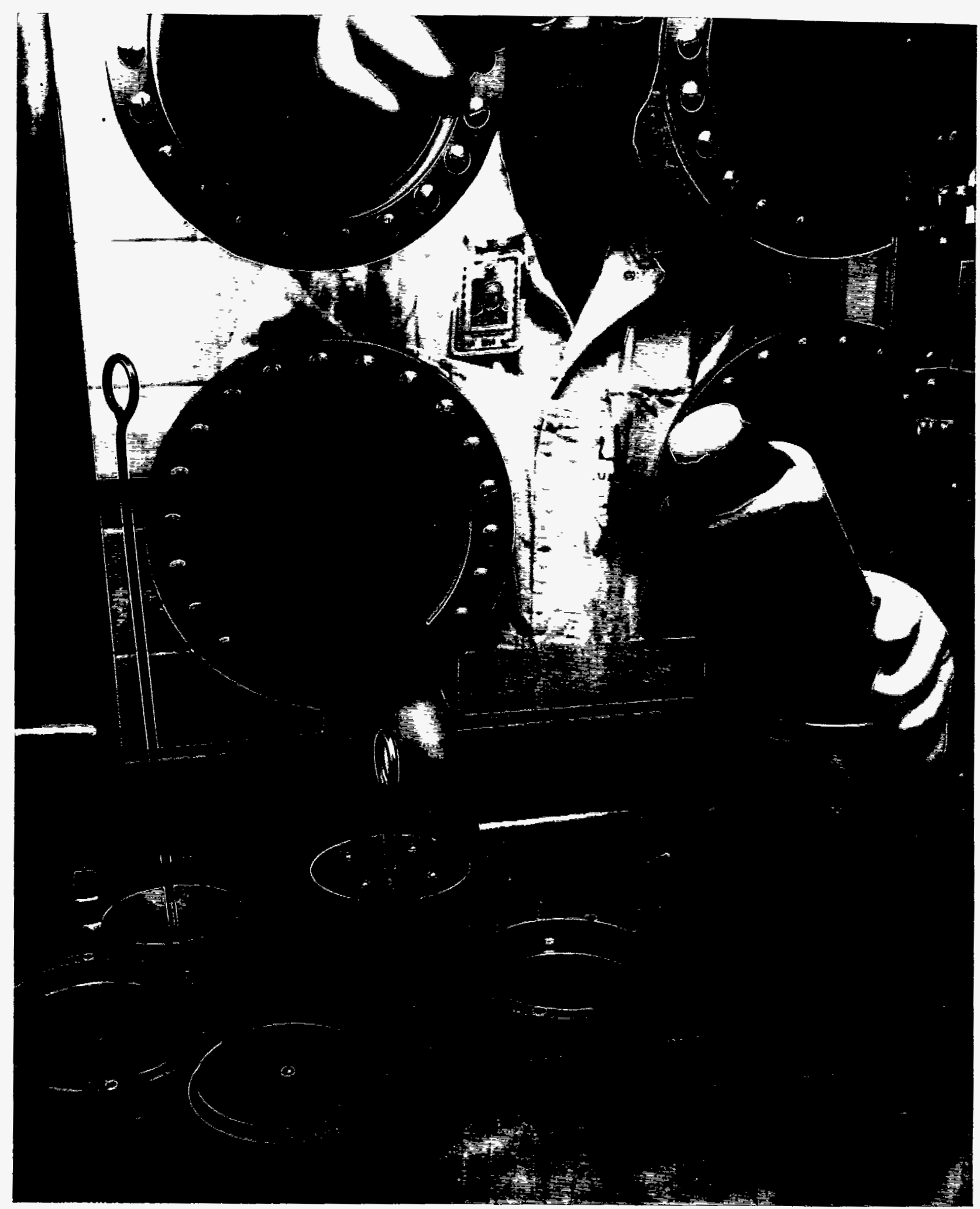

FIGURE 5 - One-liter sample being placed in calorimeter can. 


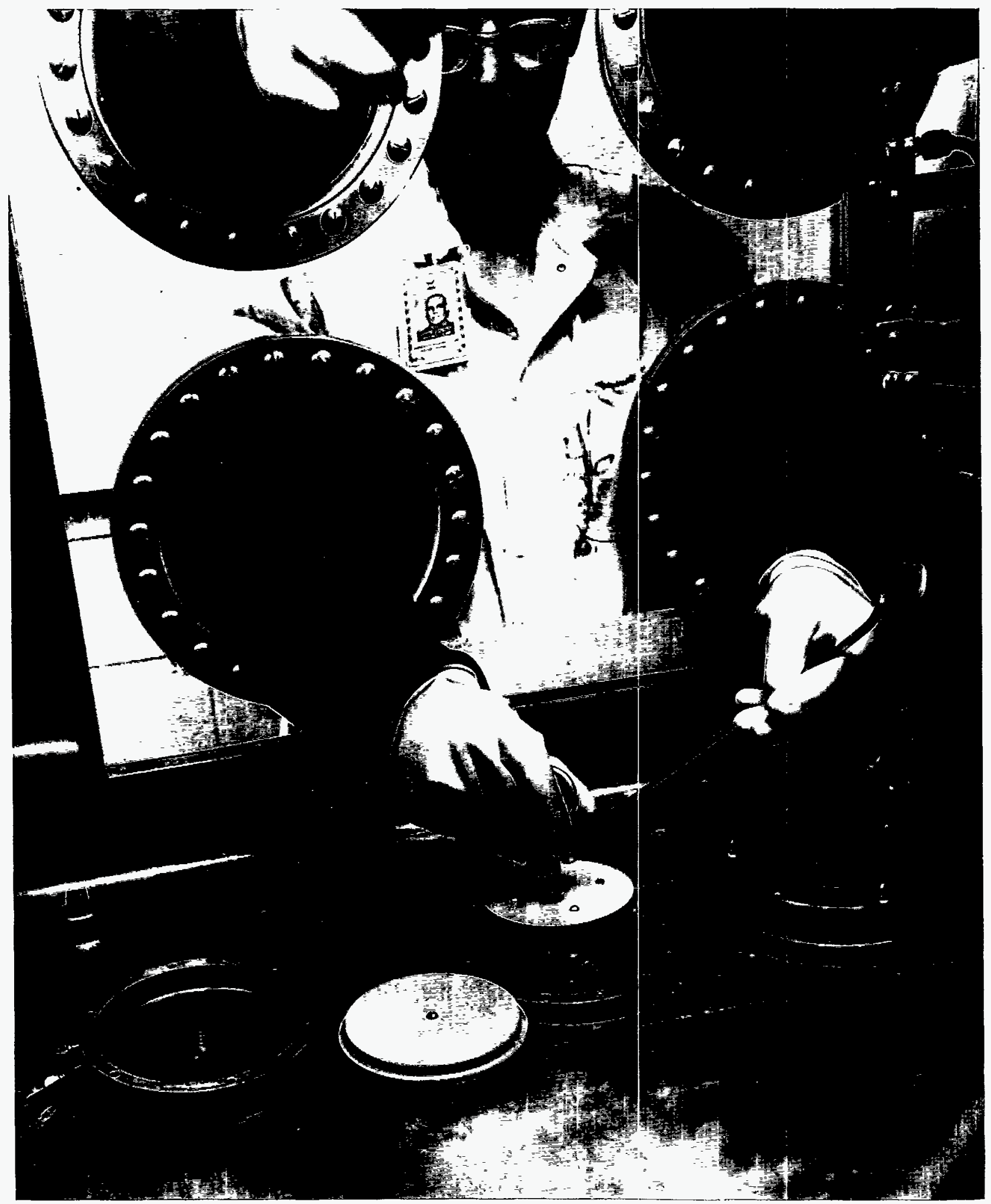

FIGURE 6 - Calorimeter sample can being placed in calorimeter. 


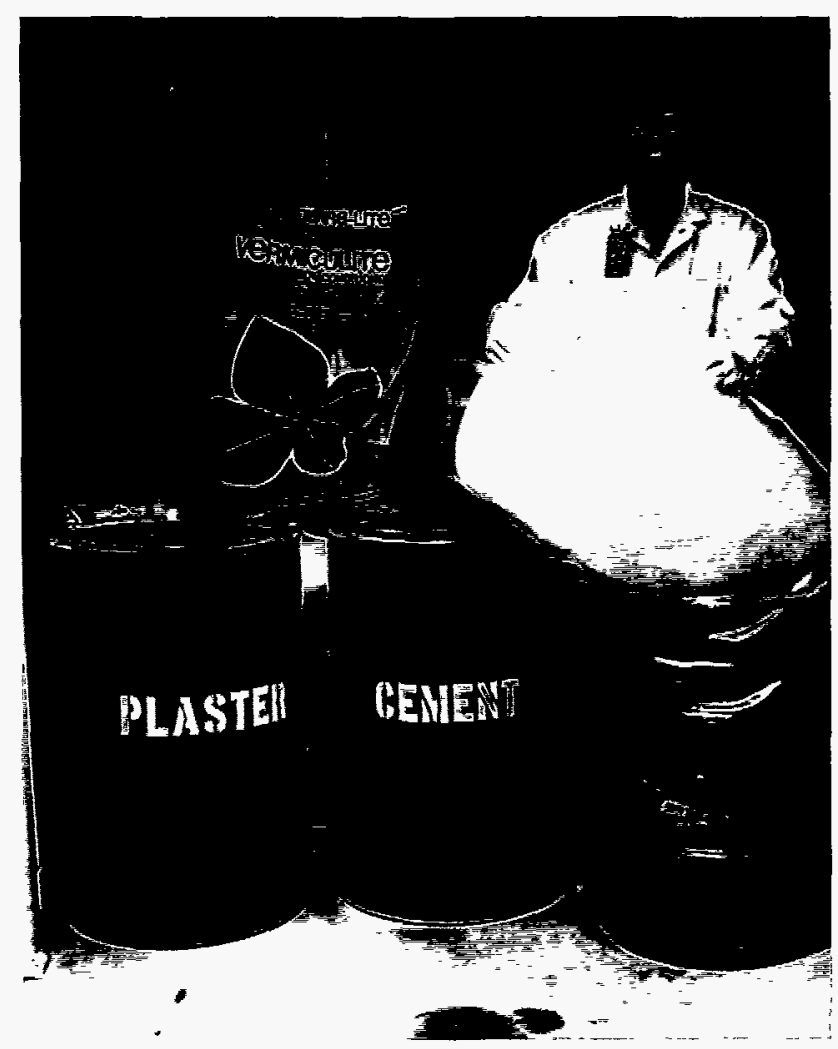

FIGURE 7 - Polyethylene drum being placed in asphalt-coated steel drum.

Figure 10). When the transfer is complete, the polyethylene drum is sealed and the inert enclosure is flushed with argon to remove residual tritium. The drum is removed from the bottom of the inert box, and the polyethylene arum is checked for leakage using a Kanné probe inside the hood enclosure. The void volume above the polyethylene drum is filled with asphalt* (see Figure 11), and the steel drum lid is sealed in place using RTV sealant and a bolted clamp ring. The steel arum is then checked for leakage using a Kanné probe.

\section{Nonstandard Containers}

Waste liquids in nonstandard containers are sampled, measured, and packaged for

*Bituminous coating, formulation to conform to specification MII-C-102A-type I. burial by the personnel originating the waste. Whenever possible, the handling and primary packaging are done in an inert enclosure to prevent exposure to personnel and release to the environment. All wastes to be packaged in the manner described below must be within the ERDA approved burial limits of $0.740 \mathrm{~g} / \mathrm{liter}$. In order to determine the total quantity of tritium being packaged for burial, an analytical sample is prepared for scintillation counting or calorimetry. One or more polyethylene bottles of appropriate size for the quantity of waste being packaged (see Table 1) are prepared as follows:

- Fór packaging wastewater the polyethylene bottle is filled with a 1:3 mixture of dry portland cement and perlited gypsum plaster. 


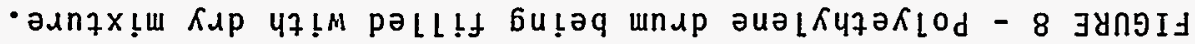

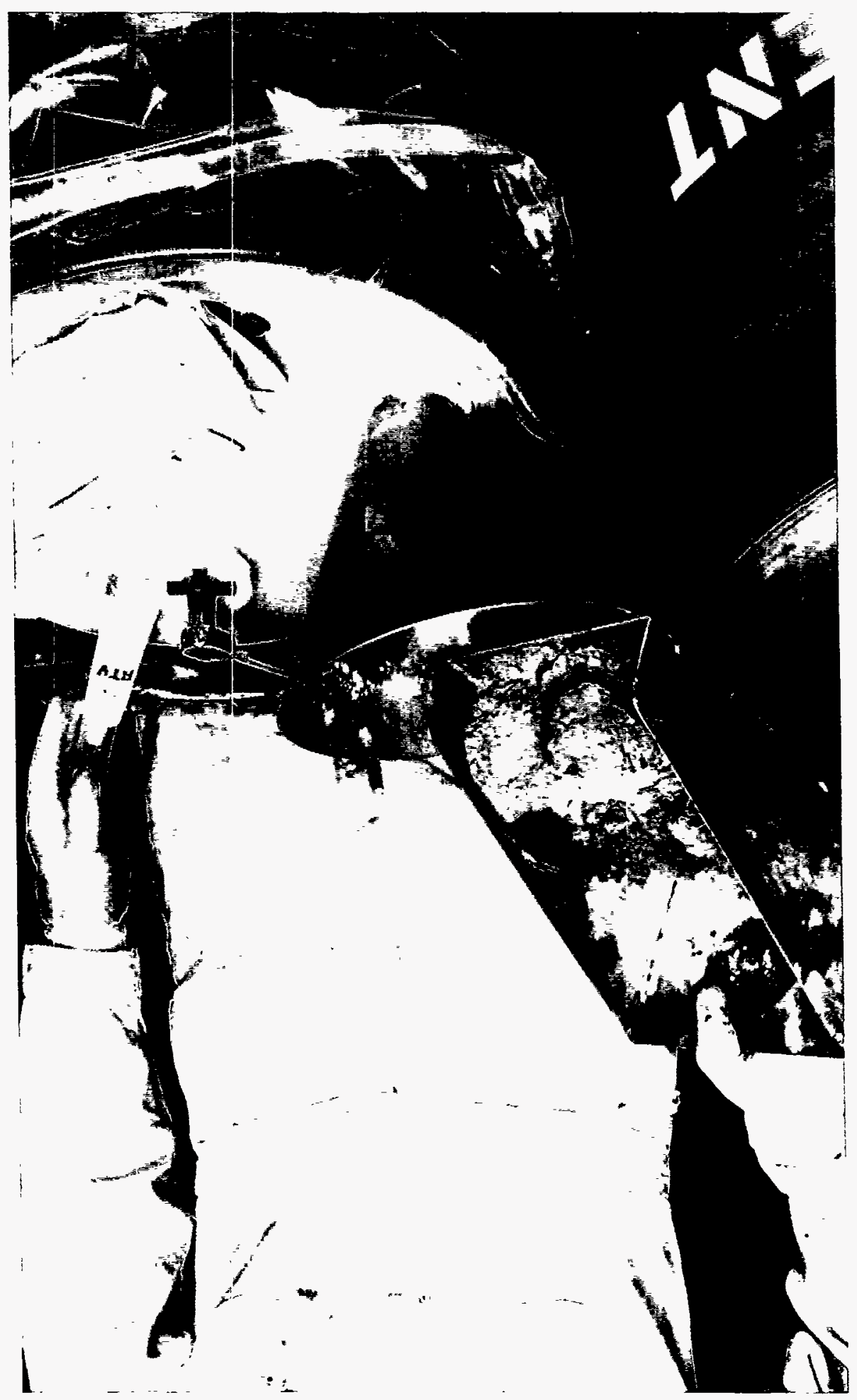




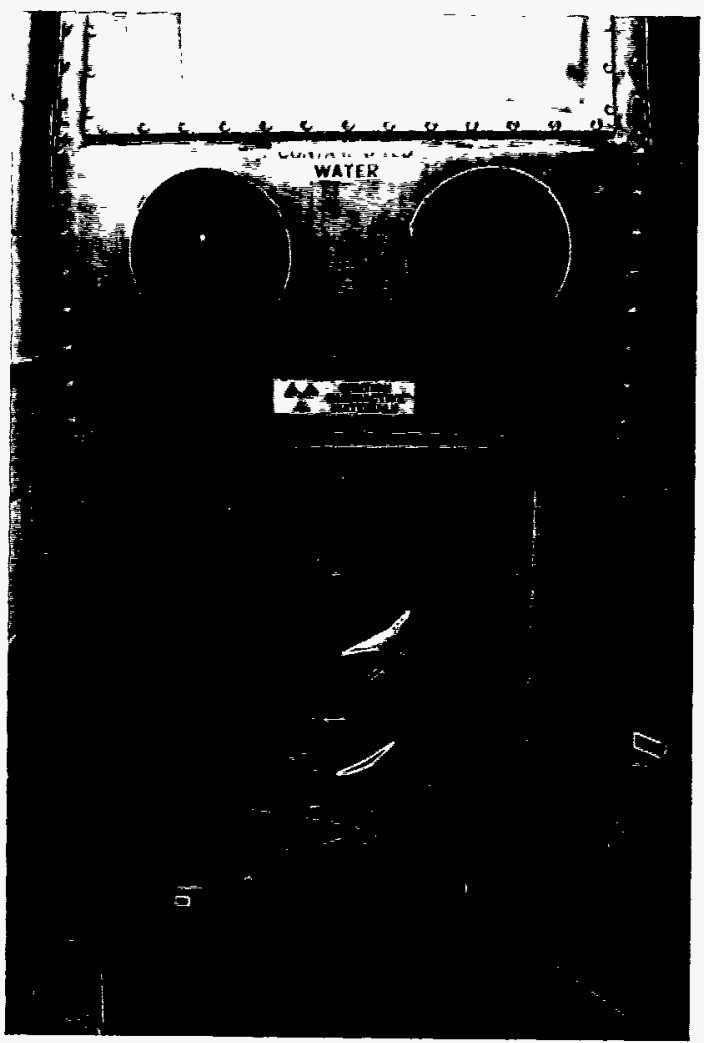

- For organic waste, such as pump oil, the polyethylene bottle is filled with dry vermiculite or Absorbal.

After analysis for tritium content, the Iiquid is carefully pumped or poured into the polyethylene bottle. The lid is tightened and sealed with RTV sealant. After removal of gross tritium contamination from the outer surface of the bottle, it is removed from the inert enclosure and placed in an asphalt-coated 30-gal steel drum. The bottle is completely covered with asphalt and the remaining void volume of the drum is filled with dry vermiculite; the drum lid is sealed by using RTV sealant and a bolted clamp ring and checked for leakage using a Kanné probe.

FIGURE 9 - Steel drum show sealed to the bottom of the inert enclosure.

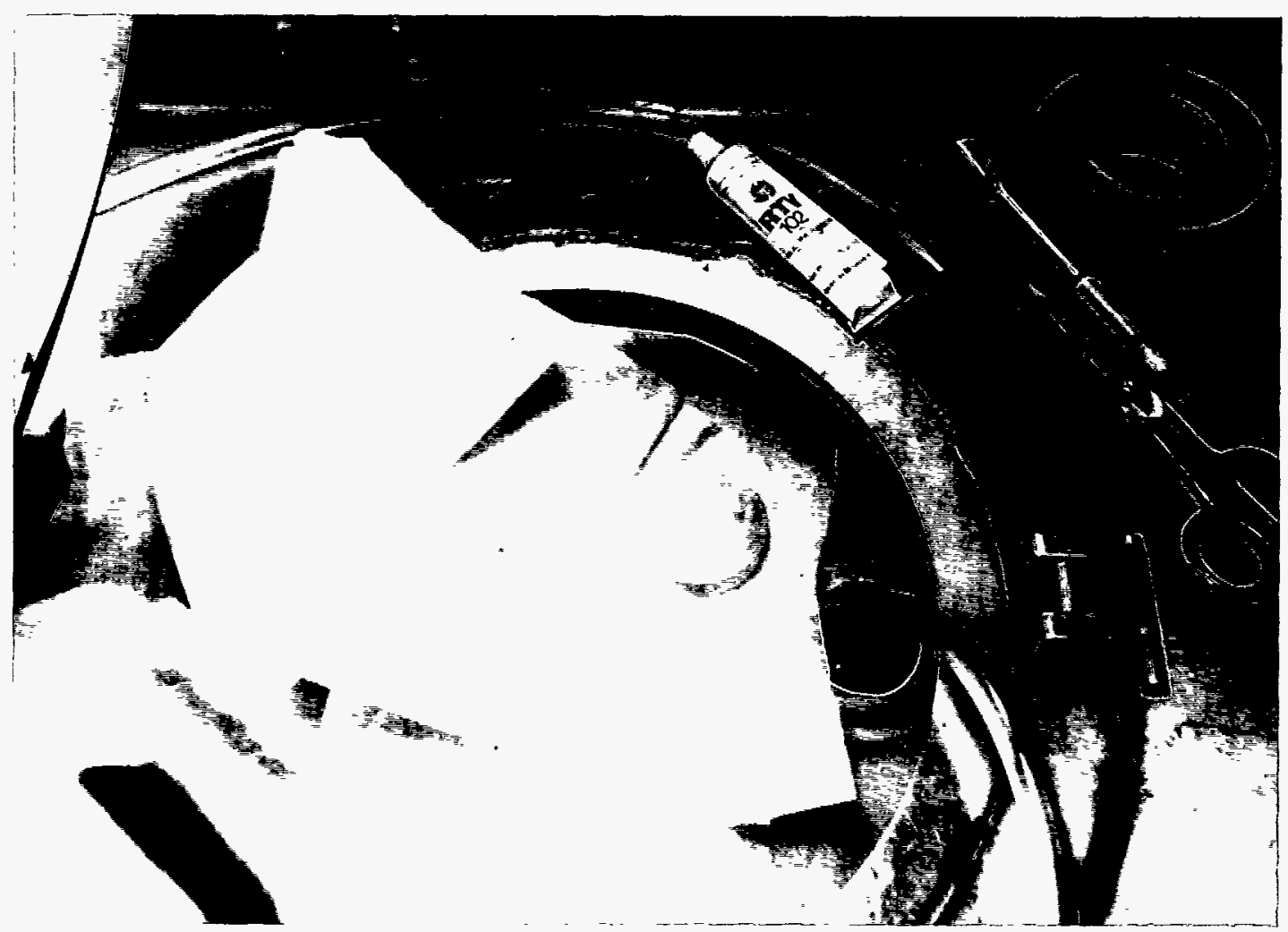

FIGURE 10 - Top of polyethylene drum (viewed through top of glovebox). 


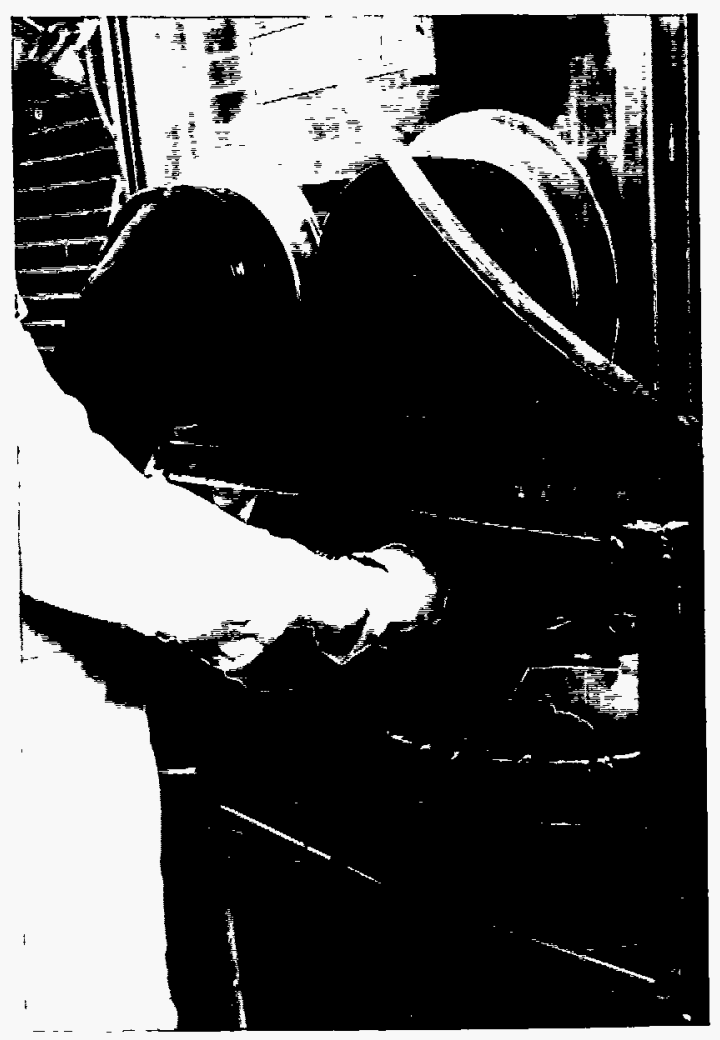

FIGURE 11 - Asphalt being poured on top of filled polyethylene drum.

\section{Final Packaging}

The sealed, 30-gal drum is centered in a 55-gal steel drum, which contains approximately 3 gal of asphalt. Vermiculite or Absorbal is then poured between the two drums to a level approximately two inches below the top of the $30-g a l$ drum lid. The remaining void volume is filled with more asphalt, and the 55gal drum lid is sealed with RTV and a bolted clamp ring. Figure 12 shows the total burial package.

\section{Burial Package Development}

The present burial package for tritiated Iiquids was designed to fulfill the following criteria:

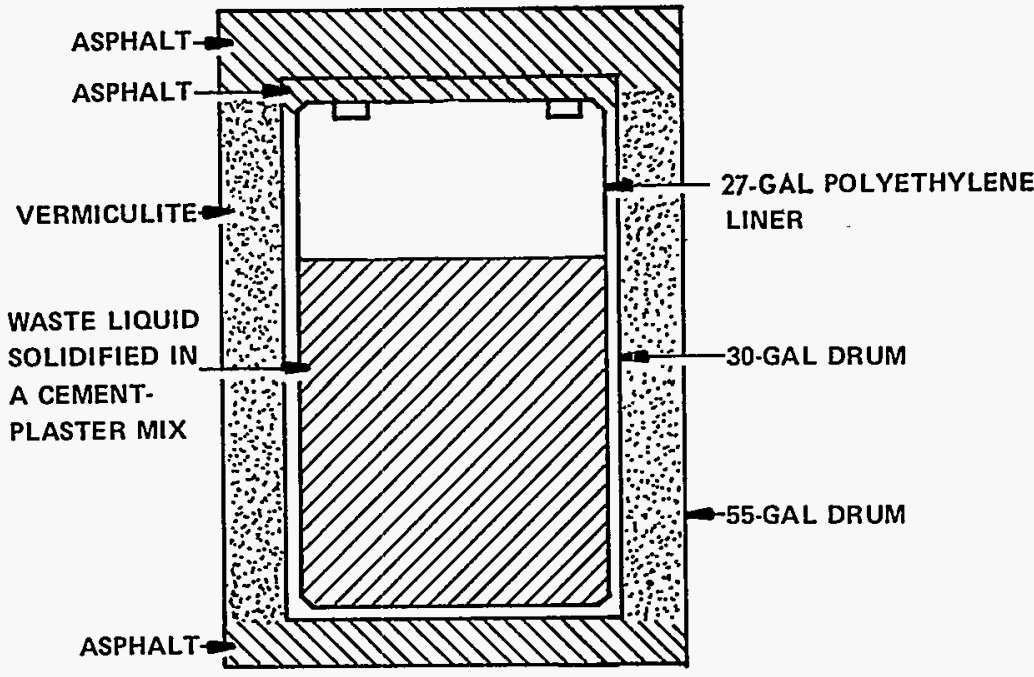

FIGURE 12 - Tritiated waste package.

- Maximum absorption of liquid.

- Minimum overall package weight.

- Resistance to corrosion by groundwaters.

- Resistance to corrosion by contained liquids.

- Resistance to permeation and leakage of tritium to the ground.

- Achieve the above results with minimum cost.

The package (see Figure 13) uses current technology and relatively inexpensive materials to meet the above requirements. Each part of the package is important in meeting the above criteria:

- For solidifying water, perlited gypsum plaster was chosen because of its light weight, high water absorption, availability, and low price. Portland Type I cement (25\%) was added to improve porosity, strength, and setting characteristics.

- For solidifying oil, vermiculite was chosen because of its high absorption and very light weight. 


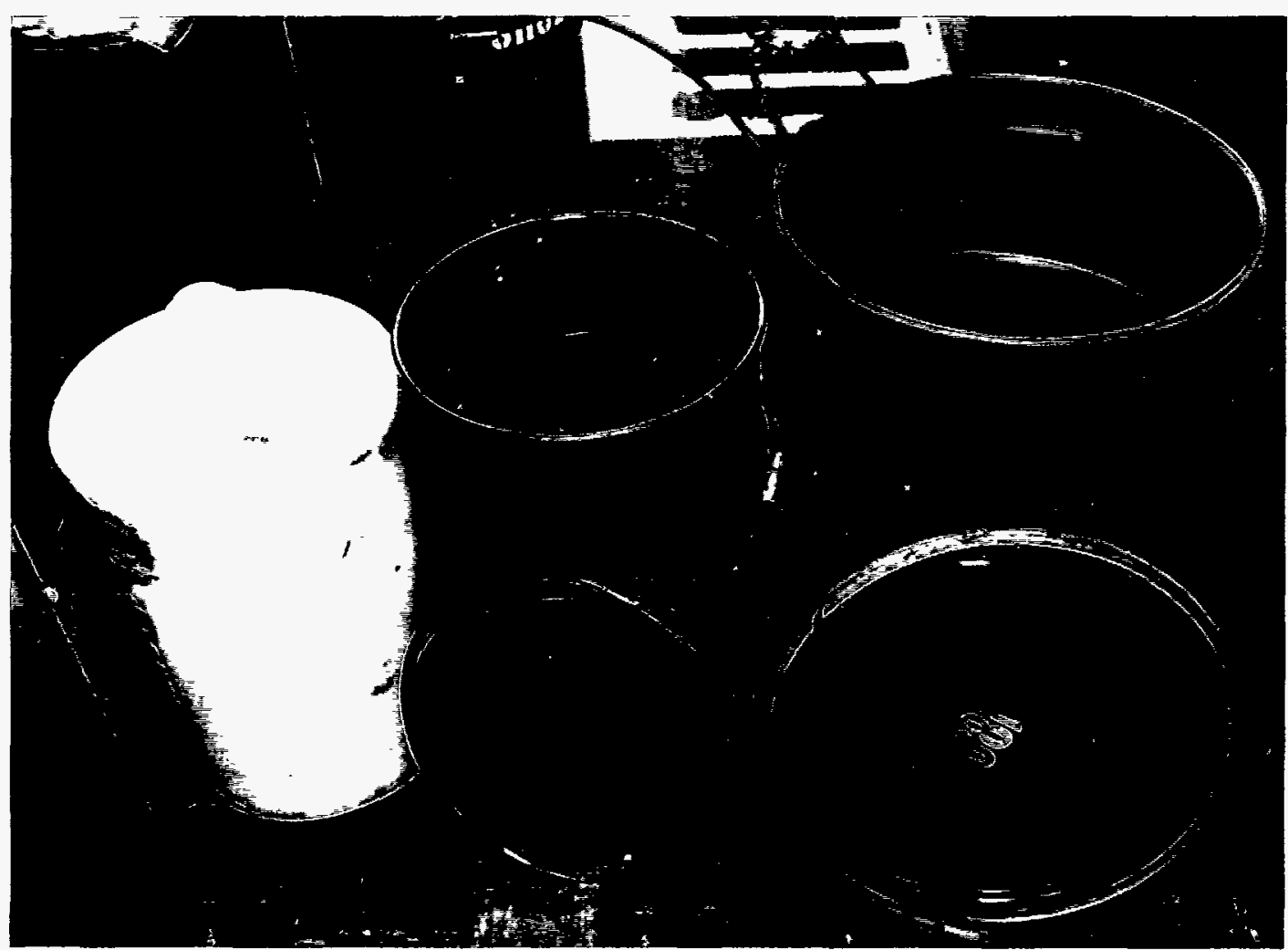

FIGURE 13 - Burial package components (shown from left to right: 27-gal primary, 30gal secondary, and 55-gal tertiary).

Absorbal, with a higher absorption but considerably more weight, is also recommended.

- Resistance to corrosion by groundwater is provided by the asphalt coating of the secondary steel drum and the use of a polyethylene primary.

- Resistance to corrosion by the contained liquid is provided by the polyethylene primary and the asphalt coated secondary.

- Permeation and leakage resistance is provided by the tertiary package; each part of which is sealed and asphalt coated top and bottom with absorbent material filling the voids between the inner and outer drums. Asphalt, being organic, also provides hydrogen atoms for exchange with tritium.
Tests are continuing to improve the burial package with a minimum increase in cost. Mound Laboratory is currently cooperating with Brookhaven National Laboratory in the development of a polymer-type solidification material that is impervious to groundwater thereby minimizing or eliminating release of tritium to the ground if the primary, secondary, or tertiary packages should fail.

\section{Burial Package Evaluation}

The present burial package has been extensively tested to verify that:

- All liquid is abosrbed or otherwise constrained in a solid form.

- The total package will contain the maximum pressure generated by total decay of the tritium $(70,000$ Ci maximum). 
- Tritium permeation through the burial package is at an acceptable level.

\section{Solidification Testing}

Examination of mock-ups of typical burial packages, which consist of 28 liters of pump oil absorbed in 24 gal of vermiculite and 35 liters of water in $24 \mathrm{gal}$ of a 1:3 cemnet-plaster mix, have shown that all of the oil and water are absorbed (that is, non-flowing) at ambient conditions.

The vermiculite in the oil-vermiculite package had an oily appearance and feel, but there was no free oil in the drum. After standing for over a year at temperatures ranging from $50^{\circ}$ to $100^{\circ} \mathrm{F}$, less than $0.5 \%$ of the total oil had separated from the absorbent.

Destructive testing of the water/cementplaster package was performed about one week after adding (without agitation) 35 liters of water to the dry cementplaster mix. Figure 14 shows the physical appearance of the cured cement: hard, dry to the touch, with no free water observed even when the block was pulverized.

\section{Pressure Testing}

Calculations have been made to determine the maximum expected increase in internal pressure, from total decay of the tritium to helium-3 after approximately $85 \mathrm{yr}$, in the existing package. With a maximum of $7 \mathrm{~g}$ of tritium in 35 liters of water producing 52 liters of helium-3 after 85 yr, the maximum pressure in the primary

\footnotetext{
ॠAfter 85 Yr, seven half-lives, approximately 18 of the original tritium would remain.
}

polyethylene drum would be 22 psig (52 liters in a 35.3-liter void). Rupture or leakage of the primary containment would reduce the pressure to 20 psig (52 liters in a 39.1-liter void). Rupture or leakage of both primary and secondary would result in a pressure of 8 psig in the tertiary containment $(52$ liters in a 103.7-liter void). Table 2 gives a summary of void volume calculations.

The information in Table 2 is believed to represent the worst case because the calculations of void volume in the primary container did not take into account the voids within the cement (which are known to be present but are difficult to measure) but only the void above the cement. Other experiences with tritiated solids indicate that when helium-3 is generated within a solid, less than half of it produces pressure in the gas phase above the solid.

Pressure tests using compressed air were performed on a 55-gal drum, 30-gal drums, and mock-ups of the total burial package. The experimental method involved submerging the sealed drums and mock-up burial packages in a large open tank filled with water (see Figure 15) then slowly filling the drums with compressed air while observing both the internal pressure (compound gauge) and the water for signs of air leakage. Results indicate the primary and secondary begin leaking about 25 psig, the tertiary at about 10 psig. More data is currently being gathered to pinpoint weak areas in the package so the total package can be improved with regard to pressure rating. 
Table 2 - VOID VOLUME CALCULATIONS

BURIAL PACKAGE DESCRIPTION:

1. $7 \mathrm{~g} \mathrm{~T}_{2}(70,000 \mathrm{Ci})$ maximum.

2. 35 liters water maximum.

3. 2-gal asphalt between 27-gal polyethylene drum and 30-gal drum. Void volume $=1$ gal or 3.8 liters.

4. 8-gal asphalt between 30-gal drum and 55-gal outer drum. Void volume $=17-\mathrm{gal}$ or 64.6 liters.

5. Remainder of void volume between 30 and 55-gal drum filled with vermiculite or Absorbal, which is assumed to occupy negligible volume.

VOID VOLUME CALCULATIONS:

1. Specific gravity of solid (1 part cement: 3 parts plaster $)=\left(1 / 4 \times 2.7^{a}\right)+\left(3 / 4 \times 1.4^{b}\right)=1.725$.

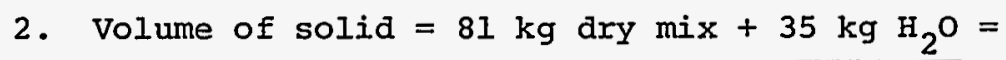
67.3 liters. 1.725

3. Void volume inside 27-gal polyethylene drum $=(27$ gal $\mathrm{x} 3.8$ ) liters/gallon -67.3 liters $=35.3$ liters .

4. Void volume inside $30-$ gal drum $=35.3$ liters + ( 1 gal $\times 3.8$ ) liters/gallon $=39.1$ liters .

5. Total void volume of 55-gal package $=35.3$ liters + 3.8 liters +64.6 Iiters $=103.7$ 1iters .

a specific gravity of cement [1] .

b specific gravity of plaster [1]. 


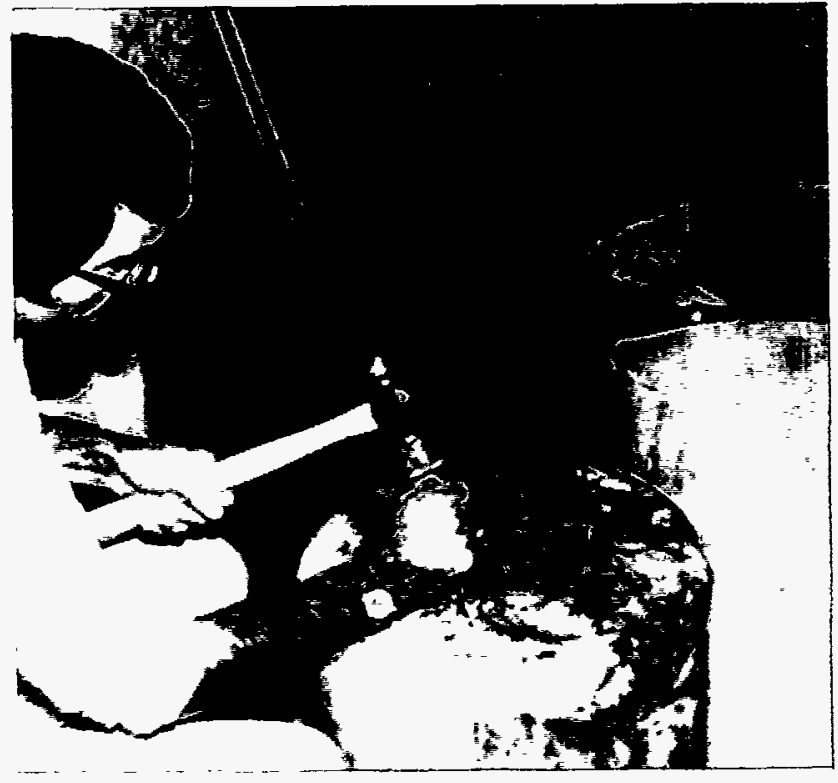

FIGURE 14 - Destructive testing of the cured cement-plaster package.

\section{Permeation Testing}

Experiments were conducted to determine the permeation of tritium from tritiated water through polyethylene, the material used as the primary burial package. The experimental apparatus (Figure 16) consisted of $16 \mathrm{oz}$. capacity, screw-cap polyethylene bottles, with wall thickness of $0.155 \mathrm{~cm}$, (in comparison, the polyethylene primary burial drum has an average wall thickness of $0.445 \mathrm{~cm}$ ) in which the tritiated liquid was contained, either as free-flowing liquid, absorbed on vermiculite or solidified in cement. Each of these containers was immersed in a wide mouth rigid plastic container containing a measured volume of water. The outer container was sealed around the polyethylene bottle at the top. To sample the water in the outer container for Iiquid scintillation counting, a small hole was drilled in the lid and fitted with a rubber stopper.

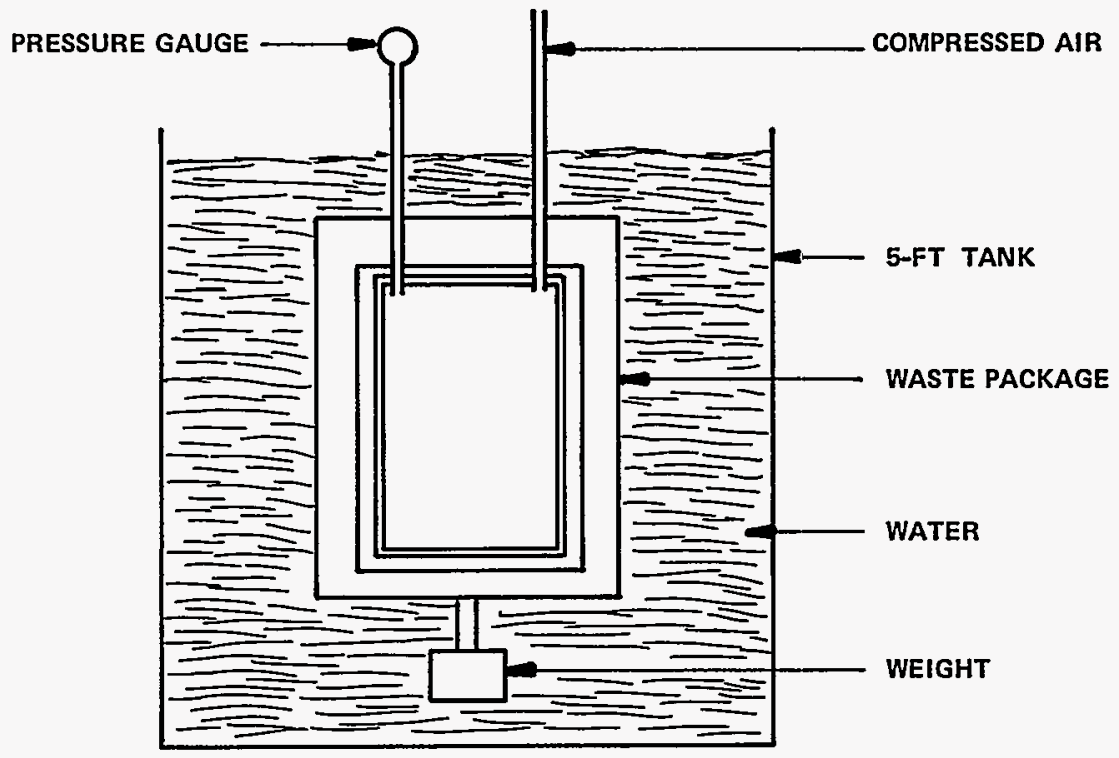

FIGURE 15 - Drum pressure test on waste package. 


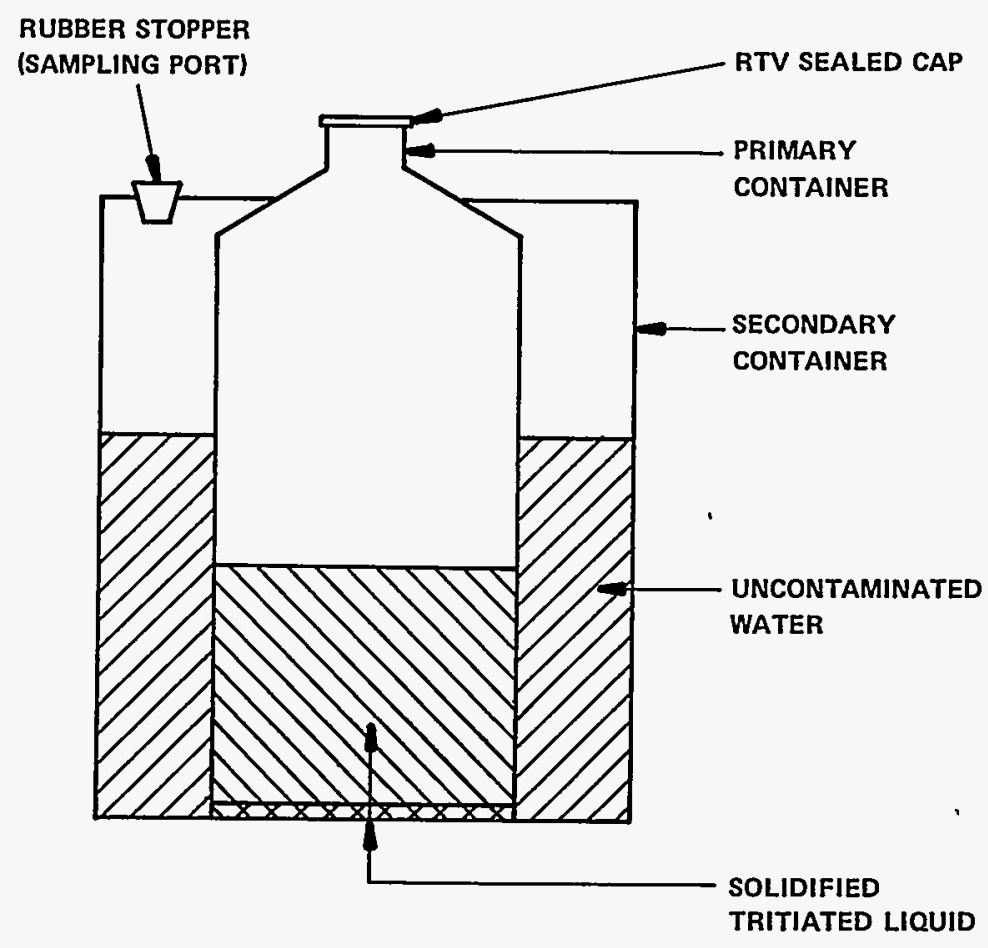

FIGURE 16 - Tritium permeation through polyethylene test apparatus.

Each primary bottle contained $200 \mathrm{~cm}^{3}$ of tritiated water with approximately 350 $\mathrm{Ci}$ of tritium. Figure 17 shows the results of the experiments. Although the initial volume of contaminated water was constant $\left(200 \mathrm{~cm}^{3}\right)$, the occupied volume depended on the absorbent material used: the vermiculite samples occupied $500 \mathrm{~cm}^{3}$, the cement-plaster 350 $\mathrm{cm}^{3}$ and the water alone $200 \mathrm{~cm}^{3}$. At the end of 13 months, calculations were made to compare equal occupied volumes (and, thus, equal surface area between the primary and secondary liquids) using data from Figure 17:

1) Vermiculite $-\frac{200 \mathrm{CC}}{500 \mathrm{CC}} \times 3.9 \mathrm{Ci}=$ $1.56 \mathrm{Ci}$

2) Cement-Plaster $-\frac{200 \mathrm{cc}}{350 \mathrm{CC}} \times 2.7 \mathrm{Ci}=$ $1.54 \mathrm{Ci}$

3) Water only - $1.43 \mathrm{Ci}$ measured
The results indicate the permeation rate is related to the surface area in contact with the tritiated material and not to the method of solidification.

Based on the above experimental results, calculations were made to determine the experimental value of the permeability constant, $\underline{k}$, for HTO through a polyethylene barrier. This value for $\underline{k}$, was then used to calculate a theoretical value for the rate of permeation, 'HTO' for HTO through the actual 27-gal polyethylene primary burial container:

If liquid water covers a surface of the area $\underline{A}$ and wall thickness $\underline{1}$, the total rate of permeation is given by [2] :

$$
\mathrm{R}_{\mathrm{H}_{2} \mathrm{O}}=\mathrm{KP}_{\mathrm{H}_{2} \mathrm{O}}^{(\mathrm{s})} \mathrm{A} / \mathrm{l} \text {, }
$$

where $\mathrm{P}_{\mathrm{H}_{2} \mathrm{O}}^{(\mathrm{O})}$ is the saturation vapor pressure of water and $\mathrm{K}$ is the permeability of water through the material. 


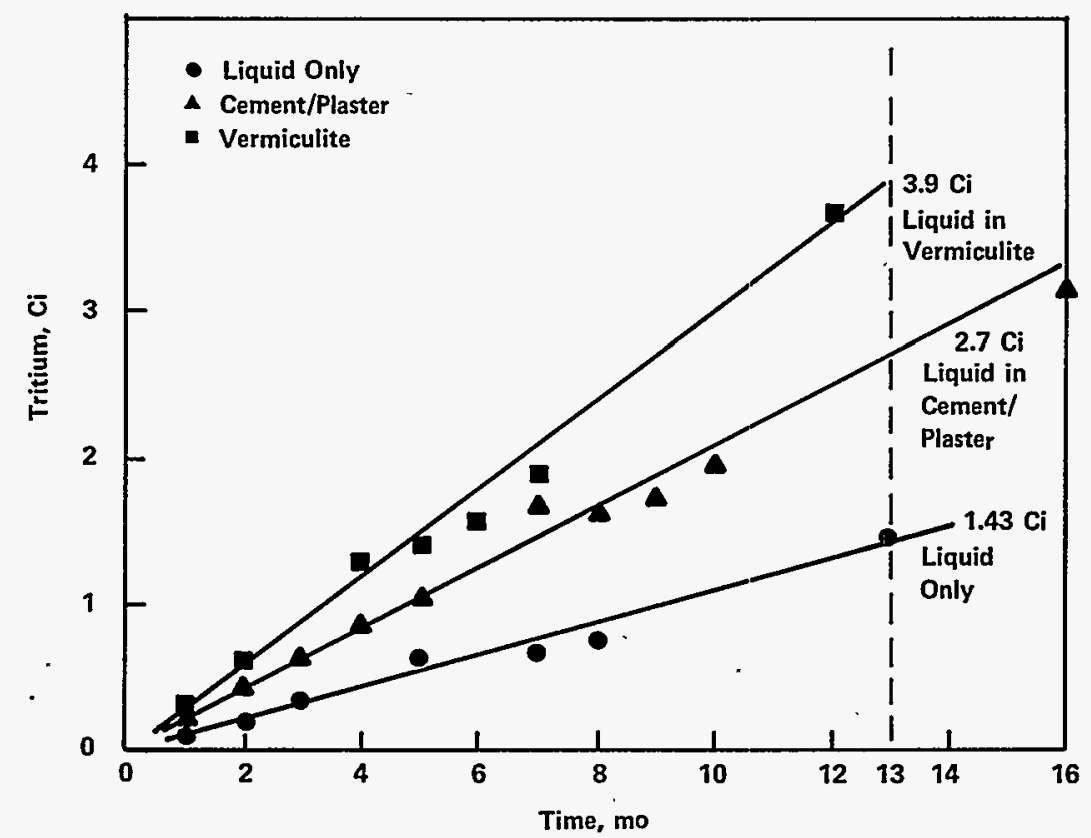

FIGURE 17 - Tritium permeation through polyethylene barrier.

If the water contains a certain molar fraction, $f$, of tritiated water (HTO), the rate of permeation of HTO is:

$$
\mathrm{R}_{\mathrm{HTO}}=\mathrm{f} \times \mathrm{R}_{\mathrm{H}_{2} \mathrm{O}} \text {, }
$$

where:

$$
f=\frac{n_{\mathrm{HTO}}}{n_{\mathrm{H}_{2} \mathrm{O}}}=\frac{a}{a} \times \frac{v_{M}}{v},
$$

where:

$$
\begin{aligned}
\mathrm{n}= & \text { moles, } \\
\mathrm{a}= & \text { the tritium activity in curies, } \\
\mathrm{a}_{\mathrm{M}=} & \text { molar tritium activity in cu- } \\
& \text { ries per mole HTO, } \\
\mathrm{V}= & \text { water volume (liters), and } \\
\mathrm{v}_{\mathrm{M}=} & \text { molar water volume in liters } \\
& \text { per mole water, }
\end{aligned}
$$

Combining (1.01), (1.02) and (1.03) gives:

$$
\mathrm{R}_{\mathrm{HTO}}=\underline{\mathrm{k} \times \mathrm{A}}
$$

where:

$$
\underline{k}=\frac{k^{P_{H}}(s)}{a_{M}} \times \nabla_{M} .
$$

Using equation, (1.04), the values of $\underline{k}$ for the sixteen ounce polyethylene bottles (with $1=0.055 \mathrm{~cm}, a=350$ $\mathrm{C} i$, and $\mathrm{V}=0.200$ liter) were calculated and given in Table 3 .

For a typical 27-gal polyethylene drum containing $38,640 \mathrm{Ci}$ in $36 \mathrm{li}-$ ters $\mathrm{H}_{2} \mathrm{O}$ held as cement-plaster, $\mathrm{R}_{\text {HTO }}$ was calculated using the experimental value for $\mathrm{k}$ given in Table $3(7.59 \mathrm{x}$ $10^{-8}$ ) and equation ( 1.04 ):

$$
\begin{aligned}
& 1=0.446 \mathrm{~cm}, A=8756 \mathrm{~cm}^{2}, \\
& a=38,640 \mathrm{Ci} \\
& \mathrm{V}=36 \mathrm{I},
\end{aligned}
$$

and

$$
\mathrm{R}_{\text {HTO }}=1.6 \mathrm{ci} / \mathrm{mo} \text { (which equals a }
$$

fractional release of $1 \times 10^{-6} /$ day or $0.004 \% / \mathrm{mo}$ or $0.05 \% /$ year of the total tritium in the primary package). 
Using a published value [3] for the permeability of $\mathrm{H}_{2} \mathrm{O}$ through polyethylene, the following value of $\mathrm{k}$ was calculated using equation (1.05):

$$
\mathrm{k}=2 \times 10^{-7} \frac{\mathrm{Ci} \cdot \mathrm{cm}}{\mathrm{cm}^{2} \cdot \mathrm{Ci} / \text { liter } \cdot \mathrm{mo},}
$$

which is in reasonable agreement with the experimental values in Table 3 .

A study of the permeation rate of tritium through the total burial package is in progress using four randomly selected actual burial packages which were prepared since 1972. The study (see Figure 18) consists of submerging each 55-gal package in a measured quantity of water and periodically analyzing the water for tritium using liquid scintillation counting. Figures 19 through 22 show the results to date and indicate the projected yearly release of tritium from each package lobtained by multiplying the most recent analytical results by the factor 52 (number of weeks since starting the tests)].

\section{Conclusions}

The data obtained from testing of the package indicate that the amount of tri- tium that would be released from the package to the groundwater each year would not exceed $0.0001 \%$ of the total tritium contained in the package. Since the yearly release will decrease by $5.5 \%$ each year because of the tritium decay, the projected maximum tritium released during $85 \mathrm{yr}$ of burial could be 0.0028 of the total tritium in the package or approximately $1.6 \mathrm{Ci}$ from the $70,000 \mathrm{Ci}$ (recommended maximum) package.

\section{Acknowledgements}

The authors gratefully acknowledge the contributions of George C. Abell, Gary E. Gibbs, and Cidney B. Voth.

\section{References}

1. LeFax Engineering Handbook, Vol. I, Lefax, Philadelphia, Penna.

2. J. Crank and G. S. Park, Diffusion in Polymers, Chap. 8, Academic Press, Iondon, 1968.

3. Ibid.

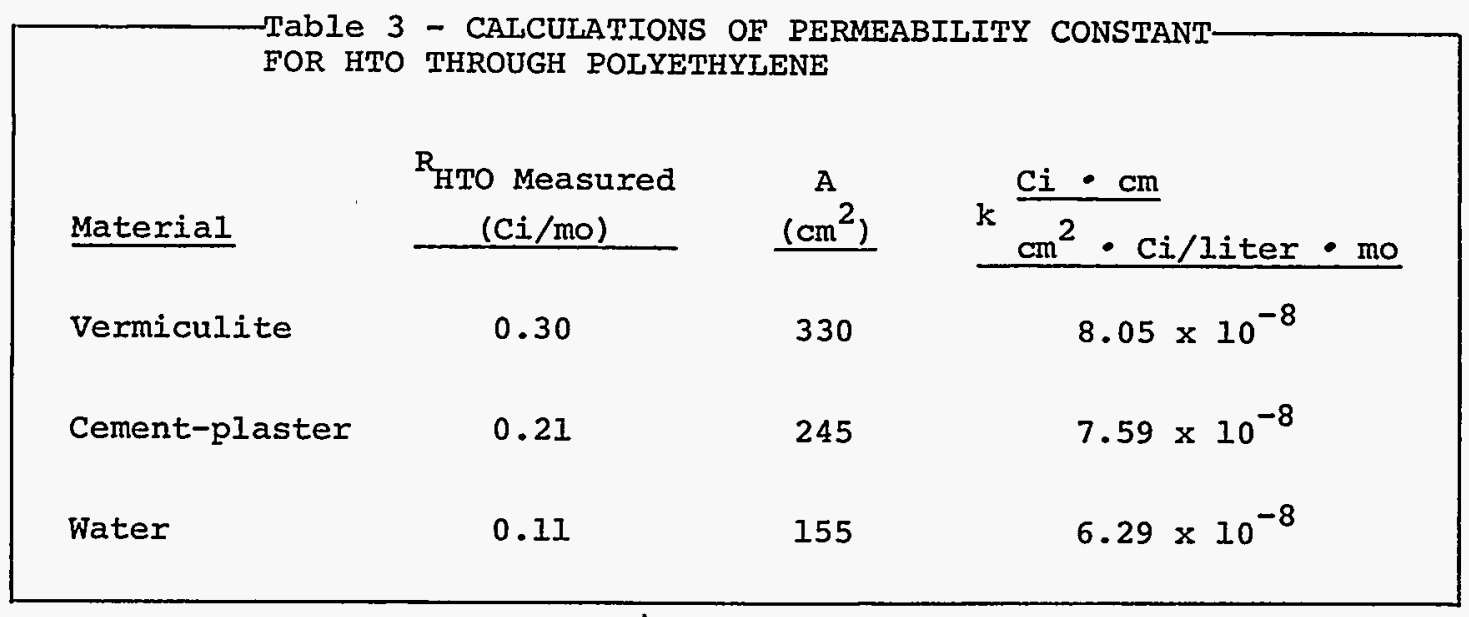




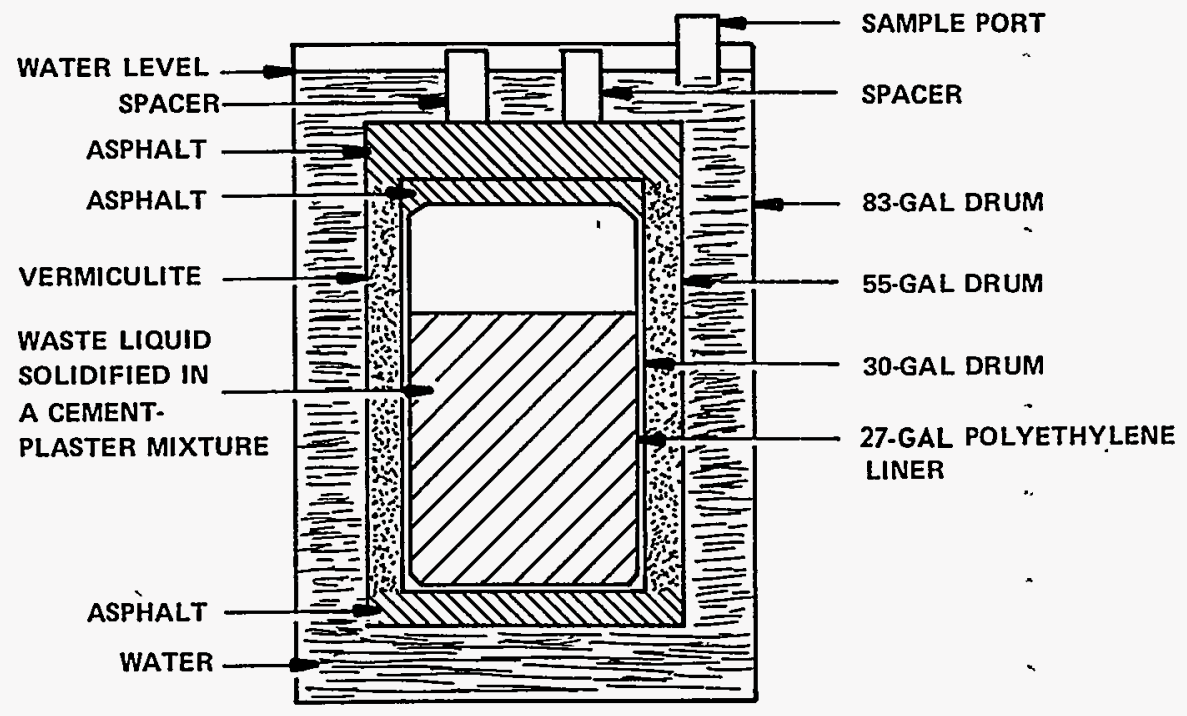

FIGURE 18 - Permeation test on tritiated waste package.

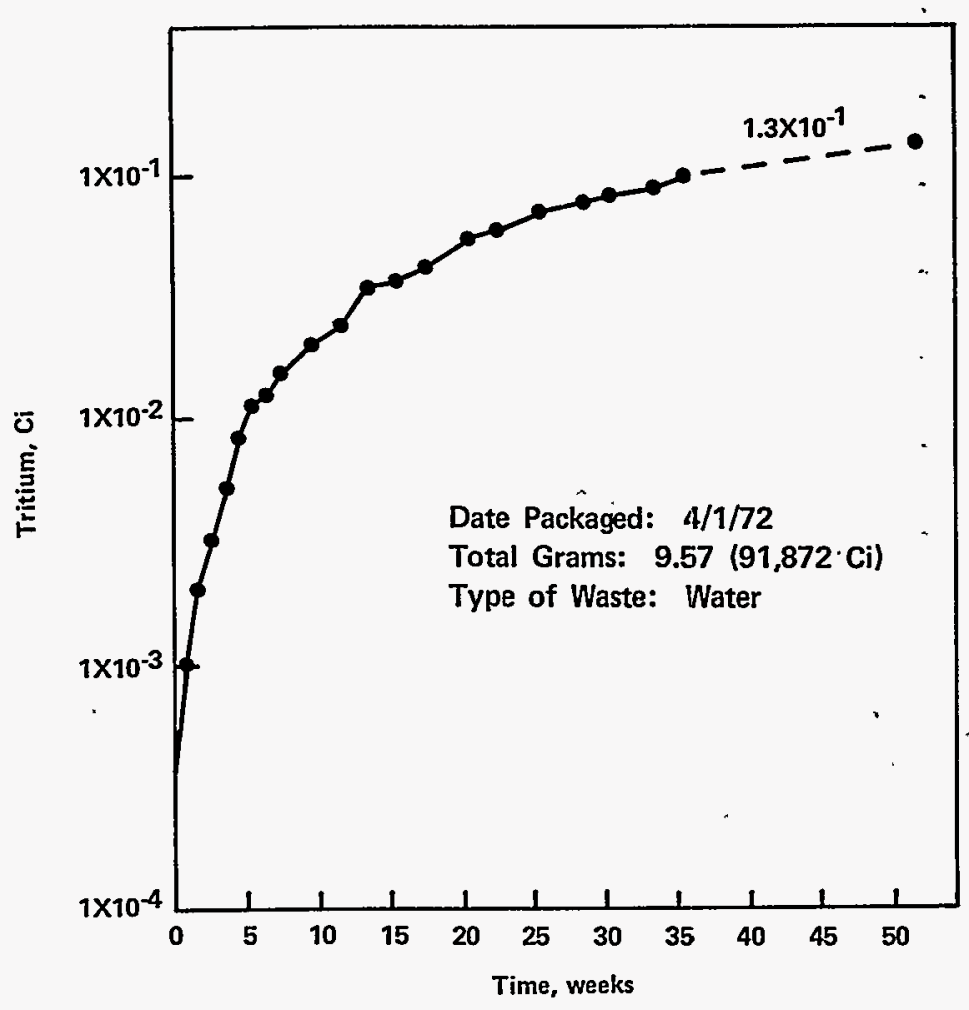

FIGURE 19 - Tritium waste package permeation rate for Drum No. 105. 


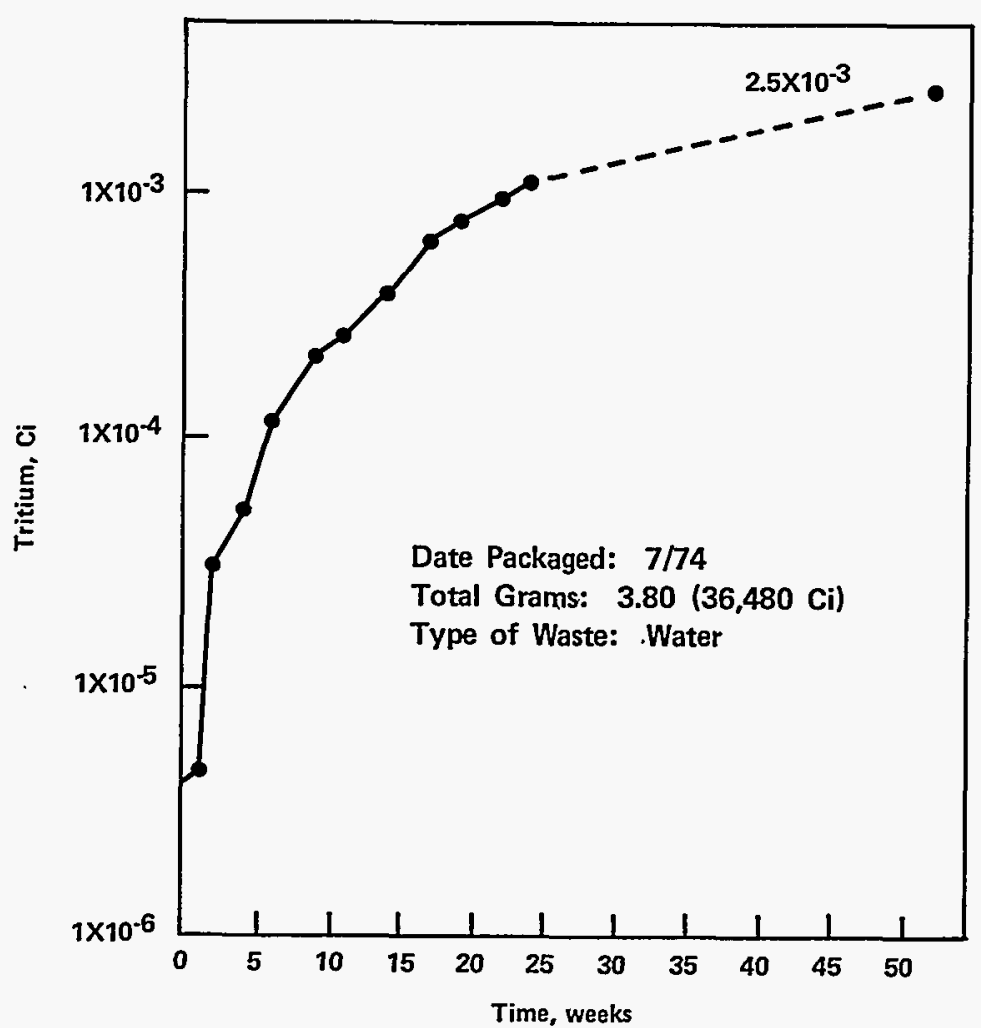

FIGURE .20 - Tritium waste package permeation rate for Drum No. 205.

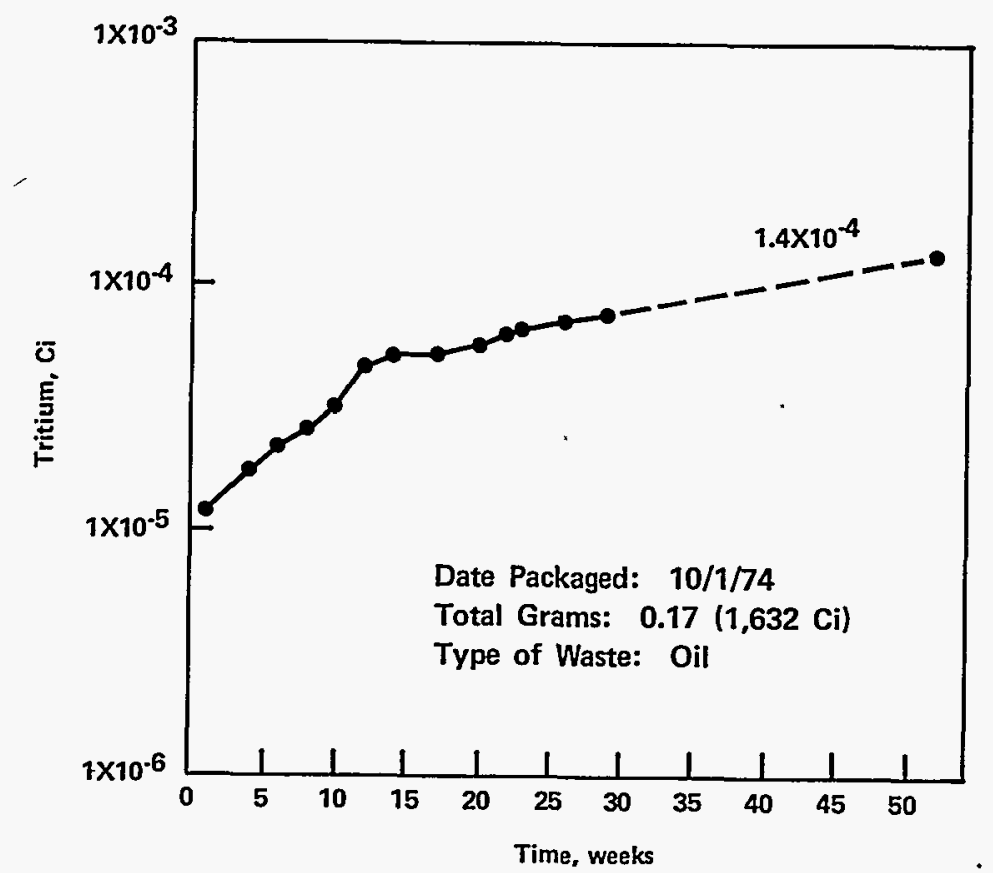

FIGURE 21 - Tritium waste package permeation rate for Drum No. 217. 


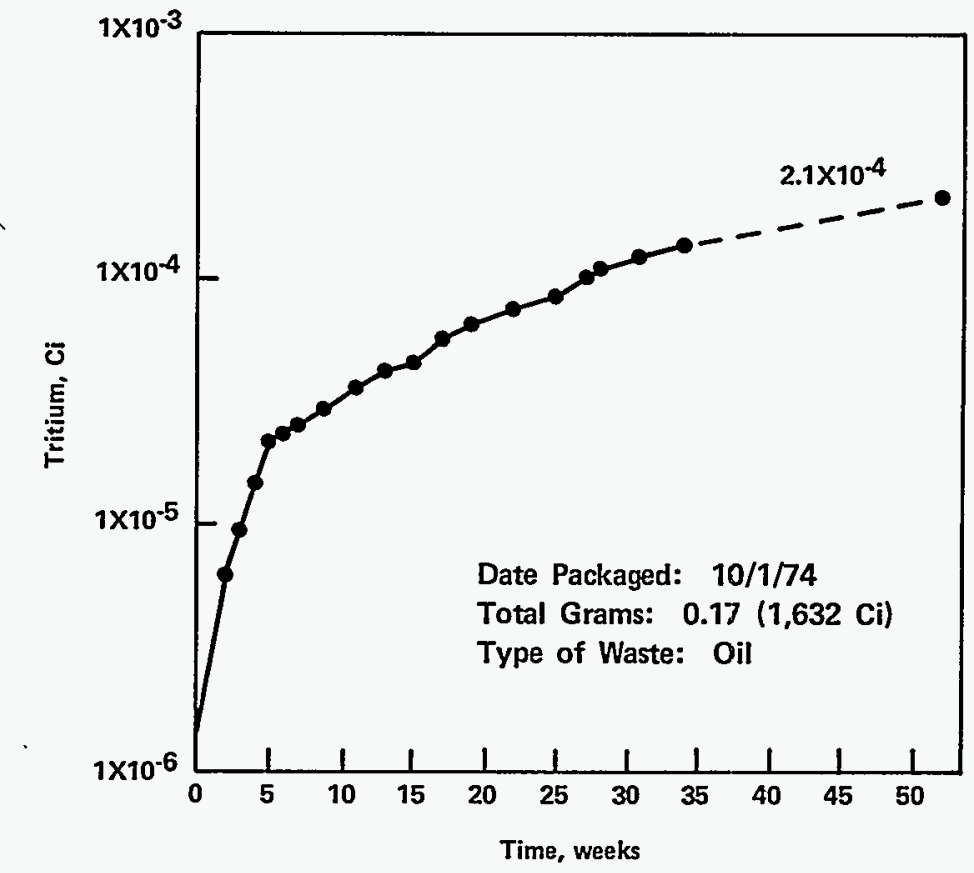

FIGURE 22 - Tritium waste package permeation rate for Drum. No. 218. 


\section{Distribution}

EXTERNAL

TID-4500, UC-70 (282)

J. A. Chacon, DAO

R. K. Flitcraft, MRC

W. E. Moddeman

A. Shapiro

Technical Report Library, Monsanto, St. Louis

Center for Atomic Energy Documentation

(ZAED), Karlsruhe, Germany

INTERNAL

G. C. Abell

H. F. Anderson

W. T. Cave

J. J. Dauby

G. E. Gibbs

C. W. Huntington

B. R. Kokenge

P. H. Lamberger

J. R. McClain

E. A. Mershad

W. W. Thomasson

C. B. Voth

Document Control Library (15)

Publications (15) 